\title{
Management for Priapism at the National Reference University Hospital Centers (NGRH) and at the Mother and Child Hospital (MCH) in Ndjamena
}

\author{
Mahamat Ali Mahamat ${ }^{1, ~}$, Kimassoum Rimtebaye ${ }^{1}$, Clotaire Amkd Yameogo ${ }^{2}$, Moussa Kalli ${ }^{1}$, \\ Olivier Ngueringeum ${ }^{3}$, Mahamat Nour Abakar ${ }^{3}$, Medjine Tchiroue Arnaud ${ }^{1}$, Oumar Atti ${ }^{1}$ \\ ${ }^{1}$ Department of Urology, Faculty of Health Sciences, University of N'Djamena, N'Djamena, Chad \\ ${ }^{2}$ Department of Urology, Yalgado Ouedraogo University Hospital, Ouagadougou, Burkina Faso \\ ${ }^{3}$ Department of Pediatric Surgery, Faculty of Health Sciences, University of N'Djamena, N'Djamena, Chad
}

Email address:

doctaali@yahoo.fr (M. A. Mahamat)

${ }^{*}$ Corresponding author

\section{To cite this article:}

Mahamat Ali Mahamat, Kimassoum Rimtebaye, Clotaire Amkd Yameogo, Moussa Kalli, Olivier Ngueringeum, Mahamat Nour Abakar, Medjine Tchiroue Arnaud, Oumar Atti. Management for Priapism at the National Reference University Hospital Centers (NGRH) and at the Mother and Child Hospital (MCH) in Ndjamena. International Journal of Clinical Urology. Vol. 4, No. 1, 2020, pp. 30-33.

doi: 10.11648/j.ijcu.20200401.17

Received: March 5, 2020; Accepted: March 31, 2020; Published: April 17, 2020

\begin{abstract}
The authors studied therapeutic and evolutionary epidemiological, etiological and evolutionary traits. This is a review of patient records admitted to the surgical emergency departments of National Reference University Hospital Centers (NGRH) and at the Mother and Child University Hospital Centers (MCH) in Ndjamena with priapism that was taken care of from 2006 to 2016. Age, consultation time, etiology, established treatment and outcomes of management were the variables studied. The series involved 31 patients, the average age was 21 . The main etiology was sickle cell priapism with $77 \%$ of cases. Six (6) patients or $19.3 \%$ had a history of prolonged erection. More than half of our patients $(52 \%)$ had consulted after 72 hours of evolution. The puncture of cavernous bodies was the most widely used therapeutic method (45\%). No major postoperative complications were recorded in the management of patients in our series. Sustained detumescence was achieved the same day or the next day in all our patients. Conclusion: Although priapism is rare in Africa, it is characterized by the predominance of sickle cell disease as etiology and the longtime of management in particular.
\end{abstract}

Keywords: Priapism, Drepanocytosis, Drainage Puncture, Cavernous Body, Chad

\section{Introduction}

Priapism is a rare uro-andrological emergency [1]. It refers to a painful and irreducible prolonged erection that occurs outside of sexual stimulation and does not result in ejaculation [2]. It is a rare condition. There are three types of priapism: ischemic, non-ischemic and intermittent, Ischemic priapism is the most common. Sickle cell patients form an overexposed group to ischemic and intermittent priapism. This ischemic form is also called stase priapism, it is the result of an abnormality of venous return due to hematological or iatrogenic causes. Diagnosis and management should be done quickly to avoid definitive sexual impotence. Several treatment options have been proposed in the management of priapism [3, 4]. The thérapeutic results remain disparate according to the authors. However, all the authors agree to underline the poor prognosis of the condition with more than $50 \%$ of érectile dysfunction in often young patients with serious social and psychological consequences [5].

This study aims to determine the etiological, therapeutic and evolutionary aspects of priapism in the two major University hospital Centers in Ndjamena.

\section{Materials and Methods}

This was a retrospective study conducted over a 10 -year 
period from January 2006 to December 2016, in the emergency departments of two centers (HURN and HUME). We identified 31 cases of priapism during this study period. Thus, were included in our study all patients received in emergency or regular consultation for painful erection, irreducible of more than four (4) hours. The following variables were selected: sociodemographic data, duration of symptoms, triggers, medical history, hemoglobin genotype, hemogram, physical signs, treatment received and evaluation of erectile function.

\section{Results}

During this study period, we collected 31 cases of priapism. The average age of our patients was 21 years with extremes ranging from 7 to 45 years and children under 10 years of age represented nearly $19.4 \%$. The age groups most represented were between (11-20 years) and (21-30 years) or 64.5\% (Table 1). Twenty (20) patients or $64.5 \%$ of our patients were single. Sickle cell disease was the main etiology $(77.4 \%)$ (Table 2). Among sickle cell patients (16 were SS homozygotes and 7 heterozygotes SC). Other etiologies included one case of chronic myeloid leukemia, one case of priapism caused by the use of traditional aphrodisiac-targeted products, one case of sildenafil overdose and 4 cases of idiopathic priapism.

The episode of priapism had occurred during sleep (90.3\%), in two (2) cases it occurred after sexual intercourse and notions of episodes of prolonged erections found in $19.4 \%$. The consultation period from the first sign of priapism was observed in $51.6 \%$ after 72 hours. In all our patients, priapism was f stase (ischemic). In $93.5 \%$ of cases, associated medical treatment was used. Twenty-nine percent (29\%) patients received ephedrine and/or diazepam administration. In almost half of the cases $(45.2 \%)$, the chosen anesthesia technique was rickets. The most commonly used therapeutic act (45.2\%). Distal caverno-spongy shunt (Al Ghorab) was used secondline in $41.2 \%$ with complete detumescence obtained on the same day in all our patients. The average hospitalization time was 10.8 days. The results of management in relation to detumescence are presented in Table 3. 24-hour recurrence was observed in 6 patients $(19.4 \%)$ all sickle cell disease. Preservation of erectile function could only be evaluated in 9 patients with an average recoil of six (6) months. The erection was satisfactory in $3.2 \%$ of cases (1/9); unsatisfactory in $6.4 \%$ (2/9) and six patients, who had consulted beyond 72 hours after the start of their priapism. The latter had presented definitive sexual impotence despite surgical treatment using Alghorab's technique.

Table 1. Breakdown of patients by age group

\begin{tabular}{lll}
\hline Age group & $\mathbf{N}$ & $\mathbf{\%}$ \\
\hline 0 -10 years & 6 & 19.5 \\
11 - 20 years & 9 & 29.03 \\
21 - 30 years & 11 & 35.48 \\
31 - 40 years & 3 & 9.67 \\
41 -50 years & 2 & 6.45 \\
Total & 31 & 100 \\
\hline
\end{tabular}

Table 2. Breakdown of Patients by Etiologies.

\begin{tabular}{lll}
\hline Etiology & $\mathbf{N}$ & $\mathbf{\%}$ \\
\hline Drepancocytosis & 24 & 77.4 \\
Chronic myeloid leukemia & 1 & 3.2 \\
Medicamenteuse & 2 & 6.5 \\
undetermined & 4 & 12.9 \\
Total & 31 & 100 \\
\hline
\end{tabular}

Table 3. Results relative to détumescence.

\begin{tabular}{lll}
\hline Detumescence & N & \% \\
\hline Complet & 23 & 74.1 \\
Partial & 2 & 6.4 \\
Recidive & 6 & 19.4 \\
Total & 31 & 100 \\
\hline
\end{tabular}

\section{Discussion}

Priapism can come in two (2) distinct forms: acute form and chronic form. The acute form includes 2 subtypes: ischemic stase or veino-occlusive priapism which is the most common (95\% of all forms) and non-ischemic priapism (high throughput or arterial). Intermittent chronic priapism (stuttering priapism of the Anglo-Saxons) is often ignored and poorly described; some authors suggest that its mechanism is also ischemic [1-4, 6].

In our study, 31 cases of priapism were collected in 10 years, representing a hospital frequency of $0.45 \%$. The overall incidence of priapism in humans is estimated at 0.3 $1.5 / 100,000$ per year [4].

The low hospital frequency is similar to that found by other African series [5-8]. In Europe, the frequency is much higher than that of African series, according to a study by Virag [9] who had 172 cases in 10 years, or 17 cases per year. This very low frequency in our series and particularly in Africa could be explained by many prejudices surrounding this pathology, since the condition concerns sexuality, modesty or ignorance which constitute factors limiting the use of consultation. Priapism appears to occur more often in children and young adults than in the elderly. In our series, the most represented age group was between 20 and 30; Kamel [5] and Fall al. [6] and also found the same age group. The average age was 21 years and the pediatric population represented $19.4 \%$ (under 10 years) in our series. This incidence varies from region to region, but remains more common in areas with high prevalence of sickle cell disease $[1,3-4,6,10]$.

In the literature, several circumstances have been associated with the occurrence of priapism. In our series, the episode occurred most often during sleep (90.3\%). It involved ten of the 22 patients in the Bouya and al series. [3] and $41 \%$ of kamel and al's series [5]. According to the literature data the decrease in partial oxygen pressure of the blood or the increase in the partial pressure of carbon dioxide noted during sleep are the most frequently encountered factors during complication of sickle cell disease. We recorded one case $(3.25 \%)$ overdose with sildenafil. Taking type 5 phosphodiesterase inhibitors (PDE5) such as sildenafil is associated with the occurrence of priapism. A case of 
priapism caused by traditional product intake has targeted aphrodisiac. This traditional product intake in our regions is often due to the limited financial resources of the population and difficult access in health facilities. The other causes reported are leukemia, traumatic and idiopathic causes [1.4], so we recorded one case of myeloid leucemia and four (4) cases of idiopathic priapism. Intra cavernous injections of erectogenic substances are currently the main etiology of priapism in Western countries $[6,11]$.

Sickle cell disease remains unquestionably the predominant etiology in our series. Several African authors have described Hemoglobinopathies as the leading cause of acute ischemic priapism [3, 8, 12]. As early as 1934, Diggs [13] had described priapism as a complication of sickle cell disease. The mechanisms behind priapism in this group of patients are varied and incompletely elucidated, but probably related to a defect in the regulation of nitrogen monoxide (NO) and the enzyme activity of type 5 phosphodiesterase [14]. In Western countries, it is responsible for nearly $3.4 \%$ of priapism compared to $86.6 \%$ of complications of intracavernous injections (ICIs) $[6,11]$. In the latoundji $\mathrm{S}$ [12] and Amadou K [2] series, also found that sickle cell priapism was more common in young adults aged 21 to $35(66.67 \%) 5$ to 15 years of age $(20.83 \%)$; and the maximum frequency was between 20 and 30 years of age $(50 \%)$ which is similar to our study.

One of the characteristics of the study of priapism in our regions is the particularly long therapeutic time. In our series, $51.6 \%$ of patients visited after 72 hours of evolution compared to only $6.5 \%$ before 12 hours. However, the literature indicates that the best therapeutic results are obtained within the first 36 hours of the evolution of priapism [15]. This delay could be explained in our context by sociocultural gravity and ignorance because everything related to sex is considered taboo, explaining the reluctance of patients to consult in the early hours of the episode.

Spinal anesthesia was the most commonly used anesthetic technique in our study, with $45.2 \%$ of cases. Other alternative techniques were general anesthesia (35.5\%) and local anesthesia (3.2\%). This is contrary to other studies, notably that of Kane and al [16] in Senegal who preferred the penile block over the spine anesthesia because of the side effect of vasoplegia maintaining priapism.

The treatment of priapism aims to achieve detumescence while preserving the erectile function of the patient. This treatment must be undertaken as a must $[1,4]$. For the patient seen early ( 24 hours), medical treatment must be initiated. In cases of priapism in a sickle cell patient, local treatment of priapism will be associated with general measures including intravenous rehydration and painkillers, oxygen therapy and possibly plasma exchanges [1, 4-5]. If medical treatment or patient treatment is not used late, an emergency surgical bypass should be performed. The principle is to create a shunt between the cavernous body and another structure (usually the spongy body) in order to "empty" the cavernous body and obtain a detumescence. The patient should be warned of the risks of erectile dysfunction as a result of priapism. First-line, a distal shunt of which there are several techniques must be made $[1,3,4,11]$ : the transglandular caverno-spongy shunt according to Winter with a biopsy gun or according to Ebbehoj with a bistouri; Al-Ghorab shunt which consists of a lateral incision in the balano-preputial furrow with excision of 5 to $10 \mathrm{~mm}$ of albuginated. In case of failure, a proximal shunt must be carried out, of which there are still several techniques [11]: the Quackels technique, which is an astomosis of at least $1 \mathrm{~cm}$ between the cavernous body and the spongy, possibly bilateral; Barry's technique, draining the cavernous body into the superficial or deep dorsal vein.

In our study, in $12.5 \%$ of cases a specific medical treatment was instituted in sickle cell disease, but was ineffective for rapid removal of priapism. A more aggressive approach was imperative to evacuate cavernous blood and allow detumescence by puncture of cavernous bodies in $45.2 \%$ of cases and by distal shunt (Al-Ghorab) after failure of puncture in $41.2 \%$. Fall and al [15] also use this technique preferentially, 12 patients were treated in their series by puncture of cavernous bodies and the other ten by the Al-Ghorab technique. The three failures of the Winter technique in the Bouya and al [3] series were treated by the Al-Ghorab technique with $100 \%$ success. All of these results are comparable to those of a review of the literature by Montague and al [17] which found an overall detumescence rate of $74 \%$ for the Al-Ghorab technique and $36 \%$ for the puncture-aspiration.

We achieved complete detumescence in 23 patients (74.1\%) and erection was satisfactory in $3.2 \%$ of cases (1/9) with an average decline of 6 months. In our series 8 patients presented a partial or total deficit of erectile function and 22 patients lost sight. The prognosis was more severe (total loss of erection) in the patient admitted beyond 72 hours, which is consistent with most of the literature $[1,4]$.

\section{Conclusion}

While the etiologies of priapism are dominated in Europe by intracavecennous injections of erectogenic substances, sickle cell disease remains the etiology predominant in Africa. The particularly long pre-therapeutic time in our regions could be reduced by staff awareness and training.

\section{References}

[1] Broderick GA and al. Priapism: pathogenesis, epidemiology, and management. J Sex Med 2010; 7 (1pt2): 476-500.

[2] Amadou. K and al. Clinical and therapeutic aspects of priapism at the Gabriel Touré University Hospital: study of 36 cases. Pan African Medical Journal. April 2014, 17: 286.

[3] Bouya PA, Lomina D. Support for priapism in 32 cases at the Brazzaville University Hospital. Afr Noire's med. 2005August/Sept; 52 (5209): 453-55. PubMed (c) Google Scholar. 
[4] Oumarou $\mathrm{H}$ and al. Management of acute ischemic priapism at Niamey African Journal of Urology Lamordé National Hospital (2017) 23, 338-41.

[5] Kamel $\mathrm{K}$ and al.: support of late-sighted low-flow priapism: about 28 cases. African Journal of Urology 2016, 22: 297-304.

[6] Fall PA, Diao B, Ndoye AK, and al (2005) Priapism: clinical and etiological peculiarities. Afr J Urol 11: 186-90.

[7] Falandry L: Priapism: treatment and results on a personal series of 56 cases. Prog. Urol, 1999, 9: 496-500.

[8] Benchekroun A. Study of priapism on 16 cases. Annal urology. 1998; 2: 103- 106. PubMed (c) Google Scholar.

[9] Virag R and al. Priapism about 172 cases. Annal of urology. 1997; 121: 642-52. PubMed (c) Google Scholar.

[10] Adeyoju AB, Olujohungbe AB, Morris J, Yardumian A, BarefordD, Akenova A, and al. Priapism in sickle-cell disease; risk factors and complications - an international multicentrestudy. BJU Int 2002; 90 (9): 898-902.

[11] C. Guillot-Tantay, Mr. Galiano. Priapism. EMC - AKOS (Medical Treaty) 2017; 12 (2): 1-4 [Article 1-0930].
[12] Latoundji S, Ahlonsou G M, Anani L, Zohoun I. Priapism sickle cell disease in Benin. Afr Noire's med. 1992; 39 (2): 122-126. PubMed (c) Google Scholar.

[13] LW Diggs. Pathology of Sickle Cell Disease. JAMA 1971; 218 (4): 600.

[14] Musicki B, Karakus S, Akakpo W, Silva FH, Liu J, Chen H, et al. Testosterone replacement in transgenic sickle cell micecontrols priapic activity and upregulates PDE5 expression andeNOS activity in the penis. Andrology 2018; 6 (1): 184-91.

[15] Fall B, Fall PA, Diao B, and al. Acute priapism associated with sickle cell disease in Senegal: clinical, therapeutic features and risk factors for erectile dysfunction. Med Too much. March 2010, 70: 475-8.

[16] Kane R and al.: Support for priapism in Dakar in 35 cases. Andrology 2012, 22: 36-41.

[17] Montague D. K and al. American Urological Association guideline on the management of priapism. J. Urol, 2003, 170: 1318-1324. 